\title{
Assessment of Physiological Equivalent Temperature (PET) in Transitional Spaces of a High- Rise Building
}

\author{
Nooriati Taib', Zalila Ali² \\ 1 School of Housing, Building and Planning, \\ 2 School of Mathematical Sciences, \\ Universiti Sains Malaysia, 11800, Penang, Malaysia \\ nooriati@usm.my
}

\begin{abstract}
One passive approach that can significantly reduce energy usage in high-rise buildings is through the creation of non-air conditioned spaces such as transitional spaces. Optimizing passive design would reduce wastage associated with the building's energy consumption. The study measures the thermal comfort of three types of transitional spaces (sky court, balcony, and rooftop) in a high-rise office building. Based on the assessment of Physiological Equivalent Temperature (PET), the outcome showed significant differences in PET in all locations in both wet and dry season. The effectiveness of such area can be improved with the contributions of landscape, maximizing natural ventilation and day lighting where possible.
\end{abstract}

Keywords: Thermal comfort; transitional spaces; high-rise; Physiological Equivalent Temperature

eISSN 2398-4295 @ 2018. The Authors. Published for AMER ABRA cE-Bs by e-International Publishing House, Ltd., UK. This is an open-access article under the CC BY-NC-ND license (http://creativecommons.org/licenses/bync-nd/4.0/). Peer-review under responsibility of AMER (Association of Malaysian Environment-Behaviour Researchers), ABRA (Association of Behavioural Researchers on Asians) and CE-Bs (Centre for EnvironmentBehaviour Studies), Faculty of Architecture, Planning \& Surveying, Universiti Teknologi MARA, Malaysia.

DOI: http://dx.doi.org/10.21834/ajbes.v3i12.118 


\subsection{Introduction}

Creating transitional spaces in high-rise development today has potential to improve thermal comfort through passive design strategies such as natural ventilation, day lighting and cooling effects of plants. These areas are described as the in between indoor and outdoor space and influenced by the microclimate (air temperature, wind velocity, radiation, and humidity) of the area. However, it is more challenging to achieve thermal comfort in these areas compared to the indoor spaces where the climate can be controlled by the air-conditioning system. It is crucial in particularly the tropical climate where it is almost possible to stay on the outside or the inside during the hot season. Outdoor spaces of hot and humid climate are often exposed to the high intensity of solar radiation. Therefore, it is important to understand the microclimate of the area to design spaces that are influenced by the outdoor condition.

\subsection{Issues and problems}

The rapid urbanization has resulted in high-rise trends due to the scarcity of land and overpopulation, particularly in the cities. The introduction of non-air-conditioned spaces such as the transitional spaces has a high potential for passive design approach, which saves more energy in building consumptions. Transitional areas in high-rise building can be in the form of a lobby, balcony, atrium, and rooftop spaces. However, it is a common sight to find these spaces to be air-conditioned to achieve thermal comfort in these areas. Research on thermal comfort has been Eurocentric and limited knowledge regarding the tropical settings (Makaremi et al. 2012). From the architectural point of view, Szokolay (2008) described the tropical region as one of the hardest climates to compromise through design. Malaysia is characterized by high temperature and high relative humidity throughout the year. Due to comfort issues, these climatic factors limit the outdoor utilization.

Previously, thermal comfort research focuses on the indoor environments of buildings. In fact, many standards have been established to define thermal comfort for indoor conditions, including both air-conditioned and non-air-conditioned areas. Recent studies on thermal comfort have now begun to address thermal comfort for outdoor conditions, most likely due to a more pressing need to utilize outdoor spaces. However, in most of these studies, indoor comfort standards were applied to outdoor conditions due to the lack of studies focusing on outdoor thermal comfort alone. The Predicted Mean Vote (PMV), Effective Temperature (ET) and Standard Effective Temperature (SET) indices have been designed for indoor use whereas Outdoor Standard Effective Temperature (OUT_SET) and Physiological Equivalent Temperature (PET) indices have been developed for the thermal comfort within outdoor environments (Spagnolo and de Dear, 2003). The OUT_SET was designed to adapt the SET indices to outdoor conditions. The current standards that are primarily used at present are Predicted Mean Vote (PMV), Physiological Equivalent Temperature (PET) and Standard Effective Temperature (SET) although problems remain in measuring outdoor comfort using these thermal indices (Chun et al., 2004). A study by Chun et al. (2004) verified that the PMV could not be used for transitional space in predicting thermal comfort due to the unstable and dynamic physical and metabolic activity (MET) value of this area. Previous literatures suggest Physiological Equivalent Temperature (PET) as the most suitable thermal index to evaluate the outdoor environment (Hoppe, 1999; Matzarakis, et al., 1999, Makaremi et al., 2011) and 
this applies to transitional spaces as well, where it is highly influenced by the outdoor climate.

\subsection{Design of transitional spaces}

Design plays a significant role in determining the effectiveness of a comfortable space. It is crucial creating an effective transitional space in the tropics where the condition is influenced by the dynamic variable of the outdoor condition i.e. unstable and prone to fluctuations of elements such as wind and temperature. A transitional space is defined as an area that is located in between the outdoor and the indoor environments, acting as both a buffer space and physical link or connections between the two areas. In most office buildings, the incorporation of transitional spaces is vital, as it functions as circulatory routes such as corridors, lift lobbies, atriums, and stairwells. In Malaysia, it is a common sight to find the use of Air-Conditioning and Mechanical Ventilation (ACMV) systems in transitional spaces when it may be more practical and economical to use natural ventilation in these spaces and still maintain the human thermal comfort (Kwong and Ali, 2011). Transitional areas allow for the opportunity of natural ventilation and daylighting in a building that acts as an energy-efficient alternative to reducing building's energy consumption. Pitts and Salleh (2007) argued that optimum energy consumption in transitional spaces is necessary for office buildings, as these areas do not usually generate "income" from the commercial activities within the premises. The passive approach is, therefore, a viable option to reduce any wastage that is associated with higher energy cost in buildings. Minimizing building's energy consumption is more pertinent now as the world struggles to cope with environmental degradation.

\subsection{Physiological Equivalent Temperature (PET) in transitional space}

Recent studies indicate that Physiological Equivalent Temperature (PET) is the most suitable option to assess thermal comfort conditions in outdoor environments rather than the indoorbased thermal indices (Makaremi et al., 2012) due to the interrelation between human body energy balance and short and long-wave radiation fluxes of outdoor spaces within PET (Lin et al., 2010). PET is termed as the physiological equivalent temperature at any given location, either outdoors or indoors and is equal to the air temperature at which, in a typical indoor setting (air temperature $=$ mean radiant temperature, relative humidity $=50 \%$, wind speed $=$ $0.1 \mathrm{~m} / \mathrm{s}$ ), the heat budget of the human body is balanced with the same core and skin temperature as compared to the complex outdoor conditions (Hoppe, 1999). This explains that the comfort conditions are dependent upon the key meteorological factors besides the personal parameters, which includes the clothing level and their metabolic rate. In various recent outdoor thermal comfort studies, PET has been employed as a universal thermal index and is irrespective of clothing (CLO-values) and metabolic activity (met values). It is clearly related to common experience as it is measured in ${ }^{\circ} \mathrm{C}$. It is well recognized for different climatic conditions to characterize the thermal comfort conditions in a physiologically significant manner.

Previous outdoor research has shown that the thermal comfort range of respondents in the tropics is higher than the European scale. Studies on outdoor thermal comfort have broadly used PET as a measuring tool for the thermal index. In comparison with thermal comfort studies in outdoor space, the thermal comfort outdoor range for Dhaka was found to 
be between $28.5^{\circ} \mathrm{C}-32^{\circ} \mathrm{C}$ (Ahmed, 2003). In Taiwan, Lin and Matzarakis (2008) concluded that the thermal comfort range would correspond to PET values of between $26^{\circ} \mathrm{C}-30^{\circ} \mathrm{C}$ (neutral perception), while there was a relatively wider "acceptable range" for slightly cold, neutral and slightly warm conditions, defined as $22^{\circ} \mathrm{C}-34{ }^{\circ} \mathrm{C}$ PET. The study found a higher neutral temperature in Taiwan $\left(22^{\circ} \mathrm{C}-34{ }^{\circ} \mathrm{C}\right)$ than in Western or Middle Europe (neutral temperature PET between $18^{\circ} \mathrm{C}-23^{\circ} \mathrm{C}$ ). This result is also in agreement with indoor comfort studies that suggest a wider thermal comfort range for tropical countries such as Malaysia compared to international standards such as ASHRAE Standard 55 and ISO 7730. This result indirectly suggests that Malaysians are acclimatized to higher environmental temperatures. Therefore, it can be argued that international standards for indoor comfort conditions should not be adopted directly without modifications to tolerate the hot and humid climates such as Malaysia as it will lead to energy waste in overcooling.

\subsection{Methodology}

The research was carried out in a 21 -storey commercial high-rise office building located in Bayan Baru, Penang (112 $50^{\prime}$ longitude and $2^{\circ} 50^{\prime}$ latitude). This building, known as the Suntech Building, was chosen as it contains three different types of transitional spaces. The transitional areas, also known as landscape gardens were labeled as Sky Court Garden (Figure 1), Balcony Garden (Figure 2.2) and Rooftop Garden (Figure 2.3) in the study. The transitional spaces were designed in three different levels in the building, varying in size, design, function and location but have a similar orientation (east-facing). All the designs were incorporated with landscape elements that vary according to the locations. The differences of the transitional spaces were described in Table 1

Table 1: A summary of typologies of the three landscape gardens

\begin{tabular}{|c|c|c|c|}
\hline & Sky Court Garden & Balcony Garden & Rooftop Garden \\
\hline Size & $213.5 \mathrm{~m}^{2}$ & $67.65 \mathrm{~m}^{2}$ & $380 \mathrm{~m}^{2}$ \\
\hline Floor to ceiling Heigh & $8 \mathrm{~m}$ & $8 \mathrm{~m}$ & Open (roof top) \\
\hline Level & $\begin{array}{l}10^{\text {th }} \text { Floor }(40 \mathrm{~m} \text { from } \\
\text { ground level) }\end{array}$ & $\begin{array}{l}12^{\mathrm{tn}} \text { Floor ( } 48 \mathrm{~m} \text { from } \\
\text { ground level) }\end{array}$ & $\begin{array}{l}21^{\text {st }} \text { Floor }(84 \mathrm{~m} \text { from } \\
\text { ground level) }\end{array}$ \\
\hline \multicolumn{4}{|c|}{ Architectural features } \\
\hline Enclosure & 1 wall & 3 walls & 1 wall \\
\hline Balcony railing & $\begin{array}{l}600 \mathrm{~m} \text { high tubular } \\
\text { steel railing on } 300 \\
\mathrm{~mm} \text { brickwork }\end{array}$ & $\begin{array}{l}900 \mathrm{~mm} \text { high brickwork } \\
\text { with cement plaster }\end{array}$ & $\begin{array}{l}1200 \mathrm{~mm} \text { high brickwork } \\
\text { with cement plaster }\end{array}$ \\
\hline \multicolumn{4}{|l|}{ Facilities } \\
\hline Gymnasium & $\begin{array}{l}\text { Gymnasium facilities } \\
\text { and sauna }\end{array}$ & None & None \\
\hline Seating Area & $\begin{array}{l}\text { Stainless steel table } \\
\text { and chairs ( } 3 \text { sets) }\end{array}$ & $\begin{array}{l}\text { Stainless steel table and } \\
\text { chairs ( } 2 \text { sets) }\end{array}$ & $\begin{array}{l}\text { Fixed stainless steel } \\
\text { benches }(6)\end{array}$ \\
\hline \multicolumn{4}{|c|}{ Transitional Features } \\
\hline Plants & $\begin{array}{l}\text { Bambusa grasilis (14) } \\
\text { Licuala grandis }(13) \\
\text { Rhaphis excelsa }(1) \\
\text { Rhaphis humilis (3) } \\
\text { Dwarf schefflera (12) }\end{array}$ & $\begin{array}{l}\text { Ptychosperma } \\
\text { macarthurii }(6) \\
\text { Licuala grandis (3) }\end{array}$ & $\begin{array}{l}\text { Bucida molineti (11) } \\
\text { Eugenia oleina }(4) \\
\text { Licuala grandis }(3)\end{array}$ \\
\hline Lighting & $\begin{array}{l}\text { Spotlights (4) } \\
\text { Bollard lights (7) }\end{array}$ & $\begin{array}{l}\text { Spotlights (4) } \\
\text { Bollard lights (3) }\end{array}$ & $\begin{array}{l}\text { Spotlights (12) } \\
\text { Bollard lights (3) } \\
\text { Decorative lamp post (3) }\end{array}$ \\
\hline Security & CCTV (2) & $\operatorname{CCTV}(1)$ & $\operatorname{CCTV~(2)~}$ \\
\hline Garden Orientation & East Facing & East Facing & East Facing \\
\hline
\end{tabular}




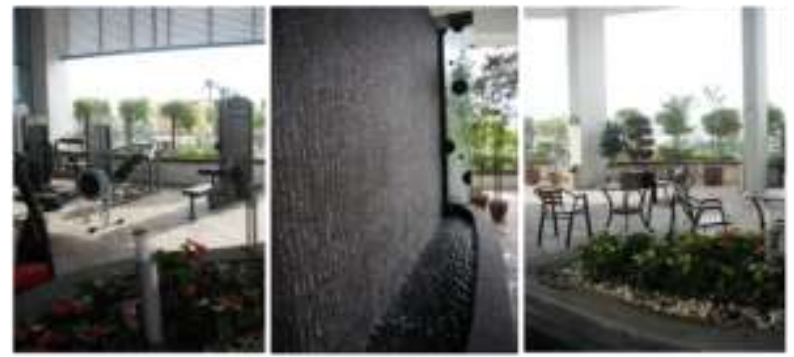

Figure 1: View of the Sky Court Garden is which located on the 10th floor of Suntech

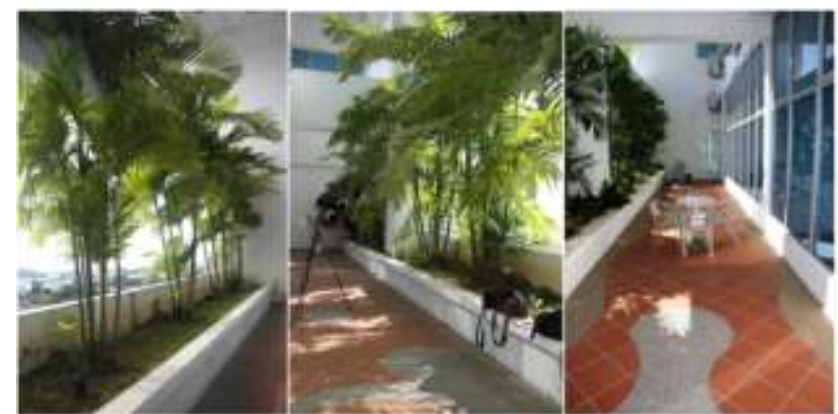

Figure 2: View of the Rooftop Garden which is situated on the $21^{\text {st }}$ floor of Suntech

Data collection was conducted in two different seasons of the same year. The first part was carried out between 8 February and 31 March 2010, which is the driest period in Malaysia (as described by the Penang Meteorology Department, 2010). The second part was carried out between 25 October and 30 November 2010, representing the wettest period in Malaysia. Equipment that were used is data logger and climate probes, taken at a height of $1.0 \mathrm{~m}$ above floor level. Probes that are connected to Babuc $A$ data logger are the wet and dry bulb temperature, air velocity fan, temperature sensor and globe thermometric. Readings were taken every 10 min at each location from 10 am to $5 \mathrm{pm}$ daily and were further classified into three different time periods: morning, afternoon and evening. The morning time was defined as 'between 10:00 am and 12:00 pm', while the afternoon was 'between 12:01 pm and 3:00 pm' and the evening period was 'between 3:01 pm and 5:00 pm'. The operating hours of the building influenced this classification.

The thermal comfort index was analyzed using Physiological Equivalent Temperature (PET). The PET of each landscape gardens was computed using Rayman software (Matzarakis et al., 2007). Calculation of thermal indices based on the human energy balance requires meteorological data such as air temperature $\left({ }^{\circ} \mathrm{C}\right)$, mean radiant temperature $\left({ }^{\circ} \mathrm{C}\right)$, wind speed $(\mathrm{m} / \mathrm{s})$, relative humidity $(\%)$, cloud cover (Octas) and thermal physiological (clothing and metabolic activity). The PET for the thermal comfort of the landscape gardens were analyzed based on a comparison between the seasons (dry and wet season) and among the landscape gardens (all three locations). 


\subsection{Statistical Analysis}

The results analyzed were the effect of season and type of location on PET readings over time. In the experiment, 24 days from both the wet and dry seasons were randomly selected using a systematic random sampling technique. Eight days of each season were then randomly assigned to each of the three different locations: Sky Court Garden, Balcony Garden, and Rooftop Garden. For each day, the four parameters of thermal comfort were repeatedly measured over three different time periods: morning, afternoon and evening. Thus, the experimental design was a repeated measure design with three factors and a repeated measure on one factor. The between- subject factors are the (i) type of season and (ii) type of location. The repeated measures factor or the within-subject factor is the time period. The subjects are the days, and the response variable is the PET value. As the air temperatures measured on the same day over different time periods were correlated, the assumption of sphericity was examined using Mauchly's test. Procedures such as the Greenhouse Geisser or the Huynh-Feldt corrections address violations of sphericity. The assumption of normality for measurement errors was tested using Shapiro-Wilks' test. A repeated measures ANOVA was then conducted to study the effect of the two different seasons and three different locations on changes in air temperature over the three different time periods. The Bonferroni multiple comparisons procedure was computed to identify differences in air temperature among locations and among seasons over each period. The field measurement data were then analyzed using Statistical Package for Social Sciences (Version 17). The significance level of the statistical tests was set at 0.05 .

\subsection{Results and Discussion}

The repeated measures ANOVA revealed a significant time period main effect ( $p$ value $=0.003$ ), which indicated that the thermal comfort index (based on PET) significantly changes over different time periods (morning, noon and evening). The presence of a significant interaction between types of season, type of location and time period ( $p$ value $=0.004$ ) further indicated that the changes in mean PET over different time periods were influenced by the type of seasons (dry and wet season) and the type of locations (all the transitional spaces measured).

Changes in PET over time were examined for the different areas for the eight randomly selected days during the dry and wet seasons. For each season, there were differences in PET readings among the days at each location and differences between the areas. In general, the mean PET during the dry season ranged from $27.14^{\circ} \mathrm{C}$ to $29.80^{\circ} \mathrm{C}$ at the Sky Court Garden, from $33.95^{\circ} \mathrm{C}$ to $31.81^{\circ} \mathrm{C}$ at the Balcony Garden, and from $37.32^{\circ} \mathrm{C}$ to $38.15^{\circ} \mathrm{C}$ at the Rooftop Garden. During the wet season, the mean PET among of the different time periods ranged from $27.24^{\circ} \mathrm{C}$ to $29.81^{\circ} \mathrm{C}$ at the Sky Court Garden, from $27.07^{\circ} \mathrm{C}$ to $28.62^{\circ} \mathrm{C}$ at the Balcony Garden, and from $32.85^{\circ} \mathrm{C}$ to $35.67^{\circ} \mathrm{C}$ at the Rooftop Garden (Table 2).

According to the overall calculated PET of the thermal condition of all the landscape gardens, an acceptable range of thermal comfort (less than $34^{\circ} \mathrm{C}$ ) was found at the Sky Court Garden and Balcony Garden, at any period of the day. Sky Court Garden showed even a lower PET (less than $30^{\circ} \mathrm{C} /$ neutral temperature) at all times regardless of the dry season 
or wet season. This finding is in accordance with findings from Lin and Matzarakis (2008) in Taiwan that proved the outdoor of hot and humid tropical region have high tolerance in a higher neutral temperature corresponded to PET value between $26^{\circ} \mathrm{C}$ to $30^{\circ} \mathrm{C}$. The study also found that the thermal comfort range of respondents was considerably greater than the Western or Middle European scale (the neutral temperature of PET between $19^{\circ} \mathrm{C}-30^{\circ} \mathrm{C}$ ). The PET value at the Sky Court Garden $\left(26^{\circ} \mathrm{C}-30^{\circ} \mathrm{C}\right)$ also reflected the user's perceptions study on thermal comfort that was conducted earlier on by Taib et al. (2012). The study showed most of the respondents perceived the Sky Court Garden as "comfortable". On the other hand, the Rooftop Garden showed a higher PET at all times compared to the Sky Court Garden and Balcony Garden with a higher PET in the dry season (hot) compared to wet season (warm). This indicates that open or non-covered rooftop are not suitable for a tropical climate compared with the design such as the Sky Court Garden and Balcony Garden; which are covered space (roof). The bare open space at the Rooftop Garden allows direct solar radiation on the roof, hence increased the PET value especially during daytime.

\begin{tabular}{lllll} 
Table 2: The changes in PET over different periods at each location during each season \\
\cline { 2 - 5 } Season & Location & Morning $\left({ }^{\circ} \mathrm{C}\right)$ & Afternoon $\left({ }^{\circ} \mathrm{C}\right)$ & Evening $\left({ }^{\circ} \mathrm{C}\right)$ \\
\hline Dry season & Sky Court & 27.14 & 29.20 & 29.80 \\
& Garden & 33.95 & 32.77 & 31.81 \\
& Balcony Garden & 37.32 & 39.17 & 38.15 \\
\multirow{5}{*}{ Wet } & Rooftop Garden & & & \\
season & Sky Court & 27.24 & 28.68 & 29.81 \\
& Garden & 27.07 & 27.88 & 28.62 \\
& Balcony Garden & 35.85 & 38.80 & 35.67 \\
\hline
\end{tabular}

The thermal indices PET should be used in measuring the thermal comfort of transitional spaces. Makaremi et al. (2012) in their study compared the small differences in ambient air temperature with differences in corresponding PET value (with a maximum value of $18^{\circ} \mathrm{C}$ ) between study areas. The PET value, unlike air temperature alone, is accumulated by the overall climatic factors such as radiation, air temperature, wind speed, and relative humidity. The study concluded that the thermal index PET was mostly affected by mean radiant temperature, Tmrt rather than ambient air temperature, $\mathrm{Ta}$, and this concludes that air temperature alone is an inappropriate indicator of thermal comfort in outdoor areas. This finding was also supported by previous studies (Mayer et al., 2008; Ali-Toudert et al., 2007) that found a stronger effect of mean radiant temperature rather than air temperature on thermal comfort values in an outdoor environment. Hence, PET was used to calculate the thermal comfort at the three landscape gardens that are influenced by the mean radiant temperature, $T_{m r t}$ due to the exposure to outdoor.

\subsection{Conclusion}

This study contributes to the existing research on thermal comfort area by focusing on transitional spaces of a high-rise office building. It has a high potential for energy savings, 
but unlike indoor and outdoor spaces, it lacks research. The PET index was used to measure thermal comfort in the transitional area; a space described as the "in between outdoor and indoor space". It is crucial in a tropical setting where there is a high potential to encourage passive design approaches such as natural lighting and natural ventilation, hence reducing energy consumption in high-rise buildings. Besides, the focus of the study on different typologies of landscape gardens allows the study to be more relevant to a wider range of space type for future design of transitional spaces in high-rise developments.

\section{Acknowledgement}

This research was funded by Universiti Sains Malaysia under Grant: 1001/PPBGN/844143 and 1001/PPBGN/ 816168.

\section{References}

Makaremi, N., Salleh, E., Jaafar, M. Z. \& GhaffarianHoseini, A. (2012). Thermal comfort conditions of shaded outdoor spaces in hot and humid climate of Malaysia. Building and Environment. 48, 7-14.

Szokolay, S. V. (2008). Introduction to Architectural Science: The Basis of Sustainable Design, Oxford, UK, Elsevier Ltd

Spagnolo, J. \& de Dear, R. J. (2003). A field study of the thermal comfort in outdoor and semi-outdoor environments in subtropical Sydney Australia. Building and Environment. 38, 721-738.

Chun, C., Kwok, A. \& Tamura, A. (2004). Thermal comfort in transitional spaces- basic concepts: Literature review and trial measurement. Building and Environment. 39 (10), 1187-1192.

Hoppe, P. (1999). The physiological equivalent temperature- a universal index for the biometeorological assessment of the thermal environment. International Journal of Biometeorology. 43, 71-75

Matzarakis, A. H., Mayer, M. G. \& Izioman (1999). Applications of a universal thermal index: Physiological equivalent temperature. International Journal Biometeorology, 43, 76-84

Makaremi, N., Salleh, E. \& GhaffarianHoseini, A. (2011). Influence of adaptation on human thermal comfort in outdoor areas of tropics. Proceeding of the First Iranian Student Scientific Conference in Malaysia. 9-10 April $2011,1-4$

Kwong, Q. J. \& Ali, Y. (2011). A review of energy efficiency potentials in tropical buildings: Perspective of enclosed common areas. Renewable and Sustainable Energy Review. 15, 4548-4553.

Pitts, A. \& Salleh, J. (2007). Potential for energy saving in building transition spaces. Energy Building. 39, 815822.

Makaremi, N., Salleh, E., Jaafar, M. Z. \& GhaffarianHoseini, A. (2012). Thermal comfort conditions of shaded outdoor spaces in hot and humid climate of Malaysia. Building and Environment. 48, 7-14.

Lin, T. P., Matzarakis A. \& Hwang R. L. (2010). Shading effect on long-term outdoor thermal comfort. Built Environment. 45, 213-221. 
Taib, N., \& Zalila Ali, Z. / Asian Journal of Behavioural Studies (AjBeS), 3(12) Jul / Aug 2018 (p.13-21)

Ahmed, K. S. (2003). Comfort in urban spaces: Defining the boundaries of outdoor thermal comfort for the tropical urban environment. Energy and Buildings. 35, 103-110.

Lin, T. P. \& Matzarakis, A. (2008). Tourism climate and thermal comfort in Sun Moon Lake, Taiwan. International Journal of Biometerology. 52, 281-290

Lin, T. P. \& Matzarakis, A. (2011). Tourism climate information based on human thermal perception in Taiwan and Eastern China. Tourism Management. 32(3), 492-500.

Matzarakis, A., Rutz, F. \& Mayer, H. (2007). Modelling radiation fluxes in simple and complex environmentsapplication of the Rayman model. International Journal Biometerology. 51(4) 323-334

Taib, N. \& Abdullah, A. (2012). Study of Landscape Gardens: Expectations and Users' Perception of a High-Rise Office Building. Procedia- Social and Behavioral Sciences. ASEAN Conference on Environment-Behavior Studies (AcE-Bs), Bangkok, Thailand 